\title{
Alternative anaesthetic management in ankylosing spondylitis
}

\author{
Şule TURGUT BALCl, ${ }^{1}$ Ayda TÜRKÖZ, ${ }^{1}$ Özlem ÇINAR, ${ }^{1}$ Hüseyin Yüce BIRCAN, ${ }^{2}$ Ümit SEKMEN²
}

Patients with ankylosing spondylitis (AS) present challenges for anesthesiologists particularly about airway management because of the limited or no cervical spine mobility, fixed flexion deformity of thoracolomber spine and possible temporomandibular joint disease. ${ }^{[1,2]}$ We describe an alternative method to prepare these patients for ventral hernia repair.

A 59-year-old male patient suffering from AS (for 25 years) with a fixed flexion deformity of cervical spine and severely decreased thoracolombar spine mobility (Fig. 1), scheduled for ventral hernia repair with anticipated difficult intubation and neuroaxial blockade. Preoperative anesthetic assessment revealed Mallampati Class IV orophariengeal view, very limited neck movement and thyromental distance was less than $6 \mathrm{~cm}$. His medical history included hypertension for 10 years and he had no other cardiorespiratuary disease. Seven years before, the patient had undergone C4-5 spine osteotomy and umbilical hernia operation under general anesthesia; in which standard spinal anesthetic technique was attempted but not successful and classic LMA has been used during the surgery due to the failed intubation of the difficult airway. In the present operation bilaterally paravertebral block (PVB) planned for the surgery and the patient was informed about the anesthetic procedure. After obtaining the written informed consent, patient was admitted to the operating room. On arrival in the operating room, routine monitoring with pulse oximeter, ECG and NIBP applied; and the patient premedicated with midazolam $2 \mathrm{mg}$ and fentanyl $50 \mathrm{mcg}$. Owing to the difficult airway access, equipment for difficult airway included LMA and fiberoptic broncoscopy were checked and kept ready. Two peripheral intravenous line and one arteriel line were placed under local anesthesia. Bilaterally thoracic PVB was performed at

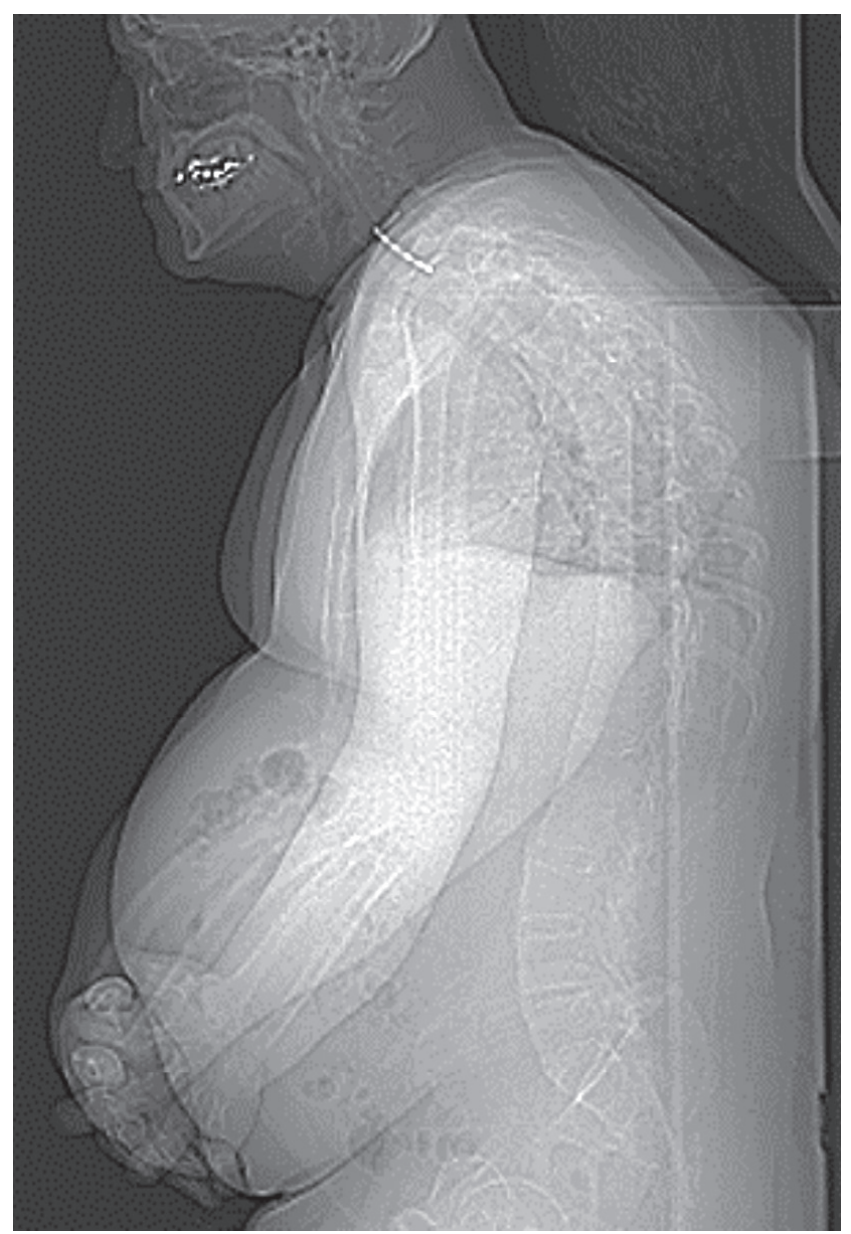

Figure 1. Fixed flexion deformity of cervical spine and severely decreased thoracolombar mobility.

\footnotetext{
'Department of Anesthesiology and Reanimation, Baskent University Faculty of Medicine, Istanbul, Turkey;

${ }^{2}$ Department of General Surgery, Baskent University Faculty of Medicine, Istanbul, Turkey

${ }^{1}$ Başkent Üniversitesi Tıp Fakültesi, Anesteziyoloji ve Reanimasyon Anabilim Dalı, İstanbul;

${ }^{2}$ Başkent Üniversitesi Tıp Fakültesi, Genel Cerrahi Anabilim Dalı, İstanbul;
}

Submitted (Başvuru tarihi) 19.06.2013 Accepted after revision (Düzeltme sonrası kabul tarihi) 03.12.2013

Correspondence (İletişim): Dr. Özlem Çınar. Oymacı Sokak, No: 7, Altunizade, Üsküdar, İstanbul, Turkey.

e-mail (e-posta): drozlem79@gmail.com 
the level of T9 by using the Lönqvist technique with the patient in the sitting position. With careful aspiration, a test dose of lidocain $\% 2,3 \mathrm{ml}$ was injected on both sides. After the negative test dose injection, levobupivacain \%0.25, $10 \mathrm{cc}$ with fentanyl $25 \mathrm{mcg}$ was injected each puncture site. Following the paravertebral injections, the patient was returned to the supine position and bilateral adequate distribution of cutaneous anesthesia up to the T4 level was determined by pinprick. Following the successful bilateral PVB with adequate sensory and motor blockade for the surgical procedure, the general surgeon repaired the umbilical hernia with a transverse incision on the previous ventral hernia incision in epigastric region. $\mathrm{BP}, \mathrm{HR}$ and $\mathrm{SpO}_{2}$ values were recorded throughout the operation. During the surgery, the patient required efedrin $5 \mathrm{mg}$ only for one time due to the MAP measurement $<50 \mathrm{mmHg}$; except he had an unremarkable course, remaining hemodinamically stable throughout the surgery. The patient didn't require any airway interventions and no further analgesic was needed during the operation. On the postoperative period no complication in relationship with the anesthetic procedure or surgery was observed. Postoperative hour 4 and 12, a total dose of morphin $4 \mathrm{mg}$ was injected through the IV route. The patient was discharged on postoperative day 1 from the hospital.

In AS patients, performing neuroaxial blocks, which include spinal and epidural anesthesia, is technically difficult because of the severe, rigid, kyphoid spinal deformity; and these patients' airway management is also difficult due to the involvement of the cervical spine and the temporomandibular joint. In case of difficult conditions for endotracheal intubation and regional anesthesia, also paravertebral blocks can be used as an alternative technique, against handicapped airway management or regional anesthesia. In conclusion, paravertebral block may be a good alternative anesthetic method for those patients.

\section{References}

1. Woodward LJ, Kam PC. Ankylosing spondylitis: recent developments and anaesthetic implications. Anaesthesia 2009;64(5):540-8.

2. Raval $C$, Patel $H$, Patel $P$, Kharod U. Retrograde intubation in a case of ankylosing spondylitis posted for correction of deformity of spine. Saudi J Anaesth 2010;4(1):38-41. 